\title{
Phenotypic and Molecular Characterization of the Capsular Serotypes of Pasteurella multocida Isolates from Pneumonic Cases of Cattle in Ethiopia
}

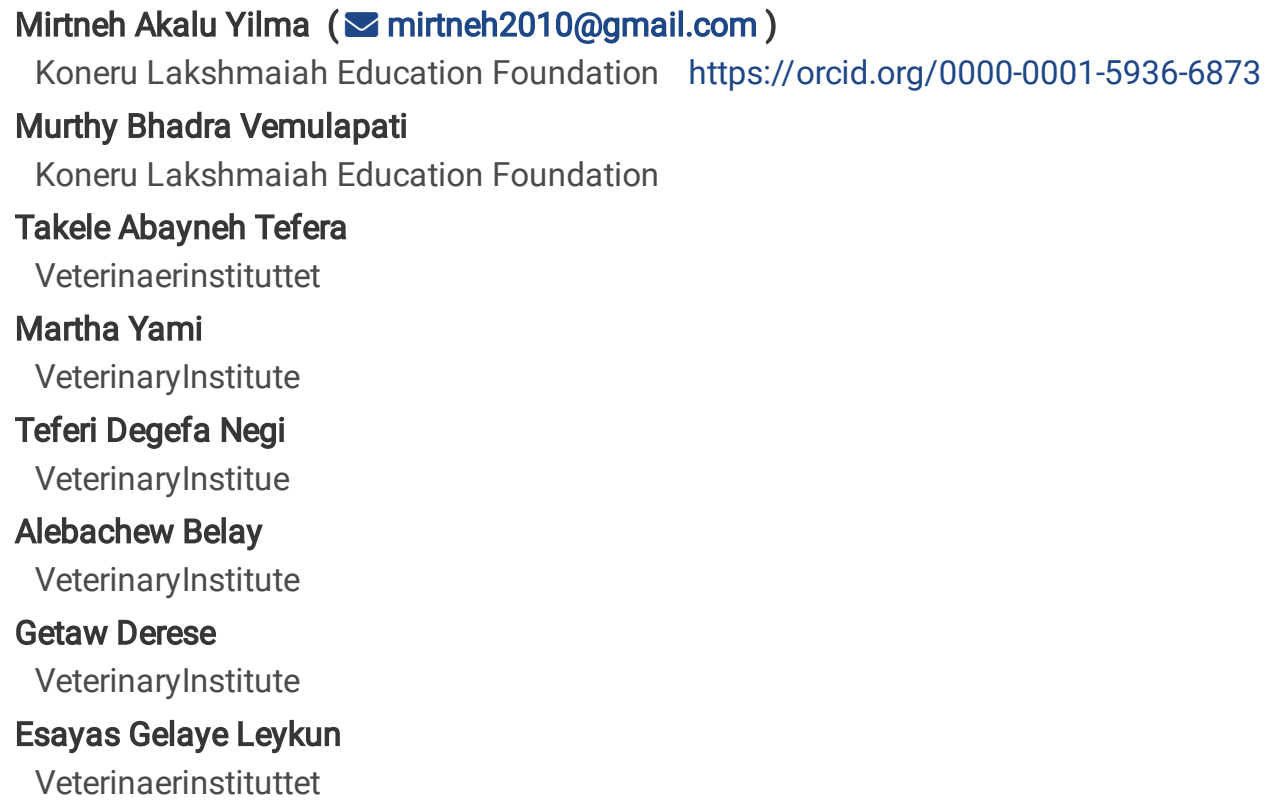

\section{Research article}

Keywords: Biovar, Capsular type, Cattle, Ethiopia, Pasteurella multocida

Posted Date: January 19th, 2021

DOI: https://doi.org/10.21203/rs.3.rs-61749/v2

License: () (i) This work is licensed under a Creative Commons Attribution 4.0 International License. Read Full License 


\section{Abstract}

Background: Pasteurella multocida is a heterogeneous species and opportunistic pathogen associated with pneumonia in cattle. Losses due to pneumonia and associated expenses are estimated to be higher in Ethiopia with limited information about the distribution of capsular serotypes. Hence, this study was designed to determine the phenotypic and capsular serotypes of $P$. multocida from pneumonic cases of cattle.

Methods: A cross sectional study with purposive sampling method was employed in 400 cattle from April 2018 to January 2019. Nasopharyngeal swabs and lung tissue samples were collected from clinically suspected pneumonic cases of calves $(n=170)$ and adult cattle $(n=230)$. Samples were analyzed using bacteriological and molecular assay.

Results: Bacteriological analysis revealed isolation of $61(15.25 \%)$ P. multocida subspecies multocida. Incidence was higher in calves $35(57.38 \%)$ compared to adult cattle $26(42.62 \%)$ at $P<0.5$. PCR assay targeting KMT1 gene ( 460 bp) confirmed $P$. multocida species. Capsular typing revealed the presence of serogroup A (hyaD-hyaC) gene ( 1044 bp) and serogroup D (dcbF) gene ( $657 \mathrm{bp})$ from $56(91.80 \%)$ and $5(8.20 \%)$ isolates, respectively. Isolation of $P$. multocida serotype A:3 highlights a new evidence in the study areas. Therefore, the current finding suggests further comprehensive studies on microbial diversity of respiratory infection in cattle to design effective control strategy.

\section{Introduction}

The genus Pasteurella is a member of the Pasteurellaceae family, which includes a large and diverse group of gram-negative Gammaproteobacteria. Pasteurella species are highly prevalent and cause several economically important endemic and epizootic diseases in a wide range of animals worldwide (Harper et al., 2006; Christensen and Bisgaard, 2010; Wilson and Ho, 2013). Characteristically, the organism is small $(0.2 \mu \mathrm{m}$ up to $2.0 \mu \mathrm{m})$, rods/coccobacilli, capsulated, non-spore-forming, non-motile and bipolar in stain. The bacterium is facultative anaerobic, fermentative and grow best with media supplemented in serum or blood (Kehrenberg et al., 2001; Quinn et al., 2002). Among members of this species Pasteurella multocida (P. multocida) is the most frequently reported heterogeneous species that causes respiratory disease and hemorrhagic septicemia in cattle (Biberstein and Hirsh, 1999).

P. multocidais a commensal and opportunistic pathogen that resides in the upper respiratory tracts of cattle (Dabo et al., 2007; Taylor et al., 2010). It is a common bacterial pathogen implicated with bovine respiratory disease (BRD), or "shipping fever", non-septicemic pneumonia (Welsh et al., 2004; Confer, 2009). Clinical manifestations range from asymptomatic or mild chronic upper respiratory inflammation to acute pneumonic and/or disseminated disease (Wilson and Ho, 2013). Pathogenesis of this organism emerges in terms of complex interaction with host specific factors such as age, diet, immune status, environment and bacterial virulence factors (Kehrenberg et al., 2001). The major virulence factors of $P$. multocida are capsular protein and lipopolysaccharide (LPS) (Harper et al., 2006). The other factors may include genes encoding structures such as fimbriae and bacterial adhesins or outer membrane proteins (Corney et al., 2007; Hatfaludi et al., 2010).

Strains of $P$. multocida are classified into five capsular serogroups (A, B, D, E, and F) according to Carter (1955) using indirect hemagglutination test and into 16 somatic or LPS serotypes by Heddleston gel diffusion precipitation assay (Heddleston et al., 1972). Polymerase chain reaction (PCR) typing has been applied as a rapid and sensitive molecular method for capsular genotyping using primers designed for species and type specific detection that was unique to all $P$. multocida strains (Townsend et al., 1998). Moreover, multiplex PCR assay was employed as an alternative technique for capsular typing with primers designed following identification, sequence determination, and analysis of the capsular biosynthetic loci of each capsular serogroup (Townsend et al., 2001). Serogroups were further classified into eight LPS genotypes (L1 - L8) according to Harper et al. (2015).

Despite the extensive research conducted over several years on respiratory disease of cattle, it continues to result in great economic impact to the cattle industry (Taylor et al., 2010). Previous studies revealed the extent of respiratory disease problems in the country and losses due to mortality, morbidity and associated expenses are estimated to be higher in Ethiopia. In those studies, P. multocida was isolated at species level as one of the major bacterial pathogens from nasal, trans-tracheal swab, and pneumonic lung samples using conventional bacteriological methods (Abera et al., 2014; Musteria et al., 2017; Gebremeskel et al., 2017). However, limited information is available regarding the capsular types and genotypes of $P$. multocida isolates circulating in the country due to lower sensitivity of detection based on phenotypic characterization. Hence, molecular advances are indispensable to understand the 
capsular Serogroups of $P$. multocida representing severe threats to the cattle population and to compile adequate epidemiological records. Therefore, the present study was designed to determine the phenotypic and molecular characteristics of $P$. multocida associated with pneumonic cases of cattle in Ethiopia.

\section{Materials And Methods Study area}

The study was conducted in selected areas of Ethiopia. Samples were collected from Asosa $\left(10^{\circ} 04^{\prime} \mathrm{N}, 34^{\circ} 31^{\prime} \mathrm{E}\right)$, Bale-Robe $\left(7^{\circ} 7^{\prime} \mathrm{N}\right.$, $\left.40^{\circ} 0^{\prime} \mathrm{E}\right)$, Bishoftu $\left(8^{\circ} 45^{\prime} \mathrm{N}, 38^{\circ} 59^{\prime} \mathrm{E}\right)$, Mekele $\left(13^{\circ} 29^{\prime} \mathrm{N}, 39^{\circ} 28^{\prime} \mathrm{E}\right)$, and Yabelo $\left(4^{\circ} 53^{\prime} \mathrm{N}, 38^{\circ} 5^{\prime} \mathrm{E}\right)$. The areas are located in different agroecological zones of highland and lowland areas from 550 to 2492 meter above sea level (Fig. 1).

\section{Sample size and sample collection}

A cross sectional survey with purposive sampling method was employed to collect samples from reported areas of pneumonic cases in cattle. Nasopharyngeal swabs and pneumonic lung tissue samples were collected from veterinary clinics and abattoir, respectively. A total of 400 samples $(n=170)$ from calves and $(n=230)$ from adult cattle were collected during the study period from April 2018 to January 2019.

\section{Nasopharyngeal swab sample}

Clinical cases of respiratory infection were inspected, and nasopharyngeal swab samples were collected from clinically sick calves and adult cattle using sterile laryngeal swab. Briefly, swab was directed via the ventral nasal meatus into nasopharynx, rotated vigorously for $30 \mathrm{sec}$ at the contralateral side. The swab was retracted and inserted into sterile screw capped test tube containing transport medium of modified Cary-Blair Medium (Park Scientific, UK).

\section{Pneumonic lung sample}

Abattoir survey was carried out on cattle slaughtered and lung with pneumonic cases were inspected for irregularity in shape, cranioventral reddening, marbling, non-friable foci, or fibrinous pleuritis (Caswell et al., 2012). Approximately a $3 \times 3 \mathrm{~mm}$ piece of lung tissue was taken aseptically from the edge of the lesion and placed in sterile universal bottle. All samples were maintained in cold chain and transported to the Research and Development laboratory of the National Veterinary Institute (NVI) of Ethiopia.

\section{Isolation and phenotypic characterization}

P. multocida strains were isolated employing standard bacteriological assay. Briefly, pneumonic lung tissue samples were minced and suspended in $4 \mathrm{ml}$ sterile physiological saline $(\mathrm{pH} 7.0 \pm 0.2)$ and centrifuged at $3260 \times \mathrm{g}$ for 3 min and supernatant was discarded. The sediment was reconstituted with $100 \mu \mathrm{l}$ sterile physiological saline. Ten $\mu \mathrm{l}$ of the suspension and nasopharyngeal swabs were streaked comparably onto blood agar base (HiMedia, India) with 5\% sheep blood and MacConkey agar (HiMedia, India). Plates were incubated at $37 \mathrm{oC}$ for $24-48$ hrs aerobically. Cultural, morphological, and biochemical assay was conducted to identify pasteurella species according to standard procedure (Quinn et al., 2002).

\section{Molecular Characterization}

\section{DNA extraction}

Genomic DNA was extracted using DNeasy ${ }^{\circledR}$ Blood and Tissue kit (QIAGEN GmbH, Germany) following the manufacturer's instructions. Briefly, $200 \mu \mathrm{l}$ sample template was transferred into $1.5 \mathrm{ml}$ microfuge tubes. $20 \mu \mathrm{l}$ proteinase $\mathrm{K}$ and $200 \mu \mathrm{l}$ buffer $\mathrm{AL}$ (lysis buffer) was added, mixed and incubated at $56^{\circ} \mathrm{C}$ for $10 \mathrm{~min} .200 \mu \mathrm{l} 96 \%$ ethanol was added, transferred into DNeasy mini spin 
column with $2 \mathrm{ml}$ collection tube, and centrifuged at 6,000 $\mathrm{x}$ g for $1 \mathrm{~min}$. Then, $500 \mu \mathrm{l}$ buffer AW1 (washing buffer) was added and centrifuged at 6,000 $\mathrm{xg}$ for $1 \mathrm{~min}$. Again $500 \mu \mathrm{l}$ buffer AW2 (washing buffer) was added and centrifuged at 20,000 $\mathrm{xg}$ for $3 \mathrm{~min}$. Finally, samples were transferred into $1.5 \mathrm{ml}$ Eppendorf tubes and $50 \mu$ buffer AE (elusion buffer) was added, centrifuged at $6,000 \mathrm{x}$ $\mathrm{g}$ for $1 \mathrm{~min}$, and the eluted DNA yield was stored at $-20^{\circ} \mathrm{C}$ until PCR assay.

\section{PCR detection of P. multocida}

PCR assay for $P$. multocida was carried out using species-specific primers. All amplification and sequencing primers were synthesized by Eurofins Genomics, Austria. Primer for the identification of $P$. multocida species was based on previous report by Townsend et al. (1998) and EL-Jakee et al. (2016) as described in (Table 1). PCR reaction mix (20 $\mu \mathrm{l}$ ) consisted of $2 \mu \mathrm{l} 5 \mathrm{pmol}$ of each primer, $10 \mu \mathrm{l} \mathrm{IQ}$ super mix (Bio-Rad), $3 \mu \mathrm{l}$ RNase free water and $3 \mu \mathrm{LNA}$ template. Amplification was carried out using thermal cycler (PCRmax ${ }^{\mathrm{TM}}$ Alpha Cycler 2, AC296, UK). Briefly, initial denaturation at $95^{\circ} \mathrm{C}$ for $5 \mathrm{~min}$, followed by 35 cycles of denaturation at $95^{\circ} \mathrm{C}$ for $1 \mathrm{~min}$, annealing at $55^{\circ} \mathrm{C}$ for $1 \mathrm{~min}$, extension at $72^{\circ} \mathrm{C}$ for $1: 30 \mathrm{~min}$, and final extension at $72^{\circ} \mathrm{C}$ for $7 \mathrm{~min}$.

\section{PCR for capsular typing}

The capsular antigens of $P$. multocida was assayed in multiplex PCR using serogroup specific primers targeting serogroups A, B, D, and $\mathrm{E}$ as described previously (Townsend et al., 2001). The oligonucleotides used were described in (Table 1). PCR reaction mix was prepared in $40 \mu \mathrm{l}$ final volume of $6 \mu \mathrm{l} 5 \mathrm{pmol}$ of each primer, $20 \mu \mathrm{l}$ of IQ super mix, $2 \mu \mathrm{l}$ RNase free water, and $6 \mu \mathrm{l}$ template DNA. Amplification was carried out at initial denaturation at $95^{\circ} \mathrm{C}$ for $5 \mathrm{~min}$, followed by 35 cycles of denaturation at $95^{\circ} \mathrm{C}$ for $1 \mathrm{~min}$, annealing at $55^{\circ} \mathrm{C}$ for $1 \mathrm{~min}$, extension at $72^{\circ} \mathrm{C}$ for $30 \mathrm{sec}$, and final extension at $72^{\circ} \mathrm{C}$ for $7 \mathrm{~min}$.

\section{Agarose gel electrophoresis of PCR products}

Amplification of PCR product was carried out in $2 \%(\mathrm{w} / \mathrm{v})$ agarose gels prepared in $1 x$ Tris borate EDTA (TBE) electrophoresis buffer. Ten $\mu \mathrm{l}$ of each PCR product was mixed with $6 \mathrm{x}$ gel loading dye and loaded into separate wells of gel. Ten $\mu$ l of DNA ladder (100 bp or $1 \mathrm{~kb}$ plus, Fermentas) was added into the last lane. Gel electrophoresis was conducted at $120 \mathrm{~V}$ for 60 min and PCR products were visualized under gel documentation system (UVI TEC, UK) stained with GelRed (Biotium, Inc).

\section{Subspecies and biovar identification}

Confirmed P. multocida isolates were assigned into subspecies based on sorbitol and dulcitol fermentation (Mutters et al., 1985; kim et al., 2019). Isolates were further classified into their respective biovars based on carbohydrate/sugar fermentation profiles including glucose, lactose, sorbitol, mannitol, trehalose, maltose, xylose, and arabinose) and ornithin decarboxylase (ODC) (Blackall et al., 1997; kim et al., 2019).

\section{Ethical statement}

Requirement compliance for animal ethics approval from University and Institution was not required for this study. Due to this reason, samples were collected from animals without experimental intervention. Consent was first obtained from the animal owners before sampling.

\section{Data analysis}

Data collected during the study period were analyzed using STATA software version 11. Descriptive statistics was used for analysis and statistical analysis was considered at $P<.05$.

\section{Results And Discussion}


Pasteurella species are highly prevalent among animal populations and economically important pathogen that cause wide range of diseases in livestock. P. multocida is a normal inhabitant of the upper airway of cattle and calves. It is likely opportunist, associated with acute and chronic infections that can lead to morbidity and mortality any time when lower airway defense mechanisms are compromised (Peek et al., 2018; harper et al., 2006; Davies et al., 2004). The present study was conducted to identify and characterize the most prevalent serotypes of $P$. multocida from pneumonic cases of cattle in Ethiopia using phenotypic and molecular methods. Clinically sick cattle exhibited coughing, high fever $\left(>39.5 .0^{\circ} \mathrm{C}\right)$, depression, anorexia, nasal discharge, lacrimation, breathing difficulty, and inappetence. Postmortem findings showed irregularity of lung shape, cranioventral reddening, marbling, non-friable foci, and fibrinous pleuritis. However, suspected cases of $P$. multocida pneumonia were confirmed with bacteriological assay.

Cultural and biochemical assay of $P$. multocida was conducted according to standard procedures (Quinn et al., 2002). Presumptive isolates were identified as small, white-creamy, mucoid, smooth, non-hemolytic growth on blood agar, and failed to grow on MacConkey agar after $24 \mathrm{hrs}$ incubation at $37^{\circ} \mathrm{C}$ (Fig. 2B). Isolates appeared as Gram-negative and small rod/coccobacilli by Gram's staining (Fig. 2A). Biochemical assay of isolates showed positive reaction for catalase, oxidase, indole production, and nitrate reduction but found negative for urease, citrate, methyl red (MR), and Voges-Proskauer (VP). Carbohydrate fermentation assay revealed identification $P$. multocida subspecies multocida (Table 2).

Phenotypic and molecular characterizations of $P$. multocida revealed an overall incidence of $61(15.25 \%)$ P. multocida subspecies multocida. $21(16.80 \%)$ and $8(10.67 \%)$ isolates were recovered from calves and adult cattle nasopharyngeal swab samples, respectively. P. multocida incidence from pneumonic lungs of calves showed $14(31.11 \%)$ and $18(11.61 \%)$ from adult cattle (Table 3). $P$. multocida incidence was higher in calves compared to adult cattle $(P<0.05)$ Hence $P$. multocida infection was significantly associated with age of cattle. Previous reports of $P$. multocida incidence ranges from $3.4 \%$ to $39.2 \%$ in Ethiopia (Abera et al., 2014; Musteria et al., 2017; Gebremeskel et al., 2017). In the present study higher incidence was identified from Bishoftu (25.0\%) followed by Bale-Robe (17.50\%), Yabelo (16.25\%), Mekele (8.75\%), and Asosa ( $8.75 \%)$. While individual cases revealed an incidence rate as high as $44.4 \%$ from calves' lung in Bishoftu.

In spite of the distribution of $P$. multocida species in Ethiopia, it is not much known about the capsular types and serotypes of $P$. multocida strains associated with pneumonic cases. Presumptive $P$. multocida isolates were confirmed by PCR assay targeting KMT1 gene fragment of species specific detection. Thus, finding revealed $\sim 460$ bp size product in all $P$. multocida isolates (Fig. 3). Although capsular typing confirmed the presence of hyaD-hyaC gene ( 1044 bp) of serogroup-A in $56(91.80 \%)$ isolates and dcbF gene ( $657 \mathrm{bp)}$ ) of serogroup-D in 5 (8.20\%) isolates (Fig. 4). The current finding is in accordance with Kong et al. (2019) who identified serogroup A as a predominant isolate from cattle. Similarly, Katsuda et al. (2013) reported isolation of capsular type A (93.7\%), D (6.3\%), and Ewers et al., (2006) identified capsular type A (93.2\%) and D (3.3\%) from cattle.

P. multocida biovar assay revealed $P$. multocida A:3 as a predominant isolate from 48 (78.69\%) cases in the study areas. P. multocida $A: 1, A: 2$, and $A: 12$ were also isolated at rate of $7(11.47 \%), 4(6.56 \%)$, and $2(3.28 \%)$, respectively. P. multocida A:3 isolates comprised capsular type A $43(89.58 \%)$ and $5(10.42 \%)$ capsular type D. All the rest isolates (A:1, A:2, andA:12) were belonged to capsular type A (Table 3). P. multocida capsular type $A$ is a principal bacterial respiratory pathogen in cattle, causing morbidity and mortality with consequent social and economic cost (Hotchkiss et al., 2010; Dabo et al., 2007). Hence, the findings of $P$. multocida capsular type A as the most prevalent pathogen from identified cases calls for further microbiological investigation and assessment of the economic impact of this pathogen at national level.

The present study revealed remarkable evidence in the distribution of $P$. multocida infection in Ethiopia. However, $P$. multocida is not the only pathogen associated with pneumonic cases of cattle and other respiratory disease bacteria, Mycoplasma species, and viruses might involve. Hence, subsequent monitoring on emerging pathogens and serotypes of $P$. multocida is essential for the development of effective control strategy in the country. The current study depicts isolation of $P$. multocida A:3 strain. Thus, the finding highlights the molecular epidemiology of isolates in the study areas. Therefore, microbiological investigation covering wider area of the country, based on outbreak report, should be carried out to assess the serotypes and genotypes of $P$. multocida isolates circulating in the country. Moreover, microbial diversity of pathogens associated with respiratory infection of cattle need to be compiled to make definite conclusion in the improvement of the existing prevention and control strategy.

\section{Conclusion}


Although many pathogens are responsible to cause pneumonia in cattle are yet to be determined in Ethiopia. The present study revealed that $P$. multocida A:3 strain is the most common serotype isolated from pneumonic samples of cattle in the study areas.

The current finding suggests further comprehensive studies on microbial diversity of respiratory infection in cattle to design effective control strategy.

\section{Abbreviations}

BHI: Brain heart infusion; DNA: Deoxyribose nucleic acid; NVI: National Veterinary Institute; PCR: Polymerase chain reaction

\section{Declarations}

\section{Ethics approval and consent to participate}

This study has been approved by the doctoral committee of Koneru Lakshmaiah Education Foundation, department of biotechnology for requirement compliance of ethical standards in handling and specimen collection from animals. Consent was first obtained from the animal owners before sampling.

\section{Consent for Publication}

Not applicable

\section{Availability of data and materials}

All data supporting the findings of this study can be obtained from the corresponding author upon formal request. Nucleotide sequence data generated in this study is submitted to GenBank Database to get accession numbers.

\section{Competing Interest}

Authors declare that they have no competing interest.

\section{Funding}

Laboratory analysis of this research was supported financially by National Veterinary Institute (NVI) of Ethiopia.

\section{Authors' contributions}

All authors participated in the conception and design of the study; MA conducted all laboratory works and drafted the manuscript. $B V, T A$, and EG analyzed the data and rigorously revised the manuscript. AB, GD, and TD participated in laboratory work. MY coordinated and revised the paper. All authors read and approved the final manuscript.

\section{Acknowledgments}

The authors highly acknowledge the animal owners and abattoir staff for allowing samples collection. Great appreciation forwarded to the Research and Development laboratory of the National Veterinary Institute of Ethiopia for providing the required facilities and support to conduct this research. The authors also thank the Department of Biotechnology, University of Koneru Lakshmaiah Education Foundation (KLEF) for supporting the study.

\section{References}

Abera, D., Sisay, T., and Birhanu, T. (2014). Isolation and identification of Mannhemia and Pasturella species from pneumonic and apparently healthy cattle and their antibiogram susceptibility pattern in Bedelle District, Western Ethiopia. African Journal of Bacteriology Research, 6(5), 32-41. DOI: http://doi:10.5897/JBR2014.0143

Biberstein, E. L. and Hirsh, D. C. (1999). Pasteurella. In: Veterinary Microbiology, eds D. C. Hirsh and Y. C. Zee, Blackwell Science Inc., pp. 135. 
Blackall, P. J., Pahoff, J. L., and Bowles, R. (1997). Phenotypic characterisation of Pasteurella multocida isolates from Australian pigs. Veterinary microbiology, 57(4), 355-360. DOI: https://doi.org/10.1016/S0378-1135(97)00111-9

Carter G. R. (1955). Studies on Pasteurella multocida. I. A hemagglutination test for the identification of serological types. American Journal of Veterinary Research, 16(60), 481-484. PMID: 13238757

Caswell, J. L., Hewson, J., Slavić, D., DeLay, J., and Bateman, K. (2012). Laboratory and postmortem diagnosis of bovine respiratory disease. Veterinary Clinics: Food Animal Practice, 28(3), 419-441. DOI: https://doi.org/10.1016/j.cvfa.2012.07.004

Christensen, H., and Bisgaard, M. (2010). Molecular classification and its impact on diagnostics and understanding the phylogeny and epidemiology of selected members of Pasteurellaceae of veterinary importance. Berliner Und Munchener Tierarztliche Wochenschrift, 123(1-2), 20-30. http://PMID:20135907

Confer, A. W. (2009). Update on bacterial pathogenesis in BRD. Animal Health Research Reviews, 10(2), 145-148. DOI: https://doi.org/10.1017/S1466252309990193

Corney, B. G., Diallo, I. S., Wright, L. L., Hewitson, G. R., De Jong, A. J., Burrell, P. C., and Blackall, P. J. (2007). Pasteurella multocida detection by 5 ' Taq nuclease assay: a new tool for use in diagnosing fowl cholera. Journal of microbiological methods, 69(2), 376380. DOI: http://doi.org/10.1016/j.mimet.2007.01.014

Dabo, S. M., Taylor, J. D., and Confer, A. W. (2007). Pasteurella multocida and bovine respiratory disease. Animal Health Research Reviews, 8(2), 129-150. DOI: https://doi.org/10.1017/S1466252307001399

Davies, R. L., MacCorquodale, R., and Reilly, S. (2004). Characterisation of bovine strains of Pasteurella multocida and comparison with isolates of avian, ovine and porcine origin. Veterinary microbiology, 99(2), 145-158. DOI:

https://doi.org/10.1016/j.vetmic-.2003.11.013

El-Jakee, J. K., Ali, S. S., El-Shafii, S. A., Hessain, A. M., Al-Arfaj, A. A., and Mohamed, M. I. (2016). Comparative studies for serodiagnosis of haemorrhagic septicaemia in cattle sera. Saudi journal of biological sciences, 23(1), 48-53. DOI: https://doi.org/10.1016/j.s-jbs.2015.06.011

Ewers, C., Lübke-Becker, A., Bethe, A., Kießling, S., Filter, M., and Wieler, L. H. (2006). Virulence genotype of Pasteurella multocida strains isolated from different hosts with various disease status. Veterinary microbiology, 114(3-4), 304-317. DOI: https://doi.org/ 10.1016/j.vetmic.2005.12.012

Gebremeskel, A. K., Tesema, T. S., Yegoraw, A. A., Birhanu, B. T., and Mekuria, S. A. (2017). Isolation and Characterization of Bacterial Species from Respiratory Tracts of Cattle Slaughtered in Addis Ababa City, Central Ethiopia. World Veterinary Journal, 7(1), 14-20. DOI: http://dx.doi.org/10.5455/wvj.20170289

Harper, M., Boyce, J. D., and Adler, B. (2006). Pasteurella multocida pathogenesis: 125 years after Pasteur. FEMS microbiology letters, 265(1), 1-10. DOI: https://doi.org/10.1111/j.1-5746968.2006.00442.x

Harper, M., John, M., Turni, C., Edmunds, M., Michael, F. S., Adler, B., ... and Boyce, J. D. (2015). Development of a rapid multiplex PCR assay to genotype Pasteurella multocida strains by use of the lipopolysaccharide outer core biosynthesis locus. Journal of Clinical Microbiology, 53(2), 477-485. DOI: http://10.1128/JCM.02824-14

Hatfaludi, T., Al-Hasani, K., Boyce, J. D., and Adler, B. (2010). Outer membrane proteins of Pasteurella multocida. Veterinary microbiology, 144(1-2), 1-17. DOI: https://doi.org/-10.1016/j.vetmic.2010.01.027

Heddleston, K. L., Gallagher, J. E., and Rebers, P. A. (1972). Fowl cholera: gel diffusion precipitin test for serotyping Pasteurella multocida from avian species. Avian diseases, 16(4), 925-936. DOI: http://dx.doi.org/10.2307/1588773

Hotchkiss, E. J., Dagleish, M. P., Willoughby, K., McKendrick, I. J., Finlayson, J., Zadoks, R. N., ... and Hodgson, J. C. (2010). Prevalence of Pasteurella multocida and other respiratory pathogens in the nasal tract of Scottish calves. Veterinary Record, 167(15), 555-560. DOI: http://dx.doi.org/10.1136/vr.c4827

Page $7 / 13$ 
Katsuda, K., Hoshinoo, K., Ueno, Y., Kohmoto, M., and Mikami, O. (2013). Virulence genes and antimicrobial susceptibility in Pasteurella multocida isolates from calves. Veterinary microbiology, 167(3-4), 737-741. DOI:

https://doi.org/10.1016/j.vetmic.2013.09.029

Kehrenberg, C., Schulze-Tanzil, G., Martel, J. L., Chaslus-Dancla, E., and Schwarz, S. (2001). Antimicrobial resistance in Pasteurella and Mannheimia: epidemiology and genetic basis. Veterinary research, 32(3-4), 323-339. DOI: https://doi.org/10.1051/vetres:2001128

Kim, J., Kim, J. W., Oh, S. I., So, B., Kim, W. I., and Kim, H. Y. (2019). Characterisation of Pasteurella multocida isolates from pigs with pneumonia in Korea. BMC veterinary research, 15(1), 119. DOI: https://doi.org/10.1186/s12917-019-1861-5

Kong, L. C., Wang, Z., Wang, Y. M., Dong, W. L., Jia, B. Y., Gao, D., and Ma, H. X. (2019). Antimicrobial susceptibility and molecular typing of Pasteurella multocida isolated from six provinces in China. Tropical animal health and production, 51(4), 987-992. DOI: https://doi.org/10.1007/s11250-018-1754-9

Musteria M., Getnet F., Anteneh W., and Yehualashet B. (2017). Isolation of Pasteurella maltocida and Mannheimia hemolytica from Pneumonic Calves and Their Antibiotic Susceptibility in Harar and Haramaya, Eastern Ethiopia. Global Veterinaria, 19 (5), $627-632$. DOI: http://10.5829/idosi.gv.2017.627.632

Mutters, R., Ihm, P., Pohl, S., Frederiksen, W., and Mannheim, W. (1985). Reclassification of the genus Pasteurella Trevisan 1887 on the basis of deoxyribonucleic acid homology, with proposals for the new species Pasteurella dagmatis, Pasteurella canis, Pasteurella stomatis, Pasteurella anatis, and Pasteurella langaa. International Journal of Systematic and Evolutionary Microbiology, 35(3), 309322. DOI: https://doi.org/10.1099/00207713-35-3-309

Peek, S. F., Ollivett, T. L., and Divers, T. J. (2018). Respiratory diseases. Rebhun's Diseases of Dairy Cattle, 94. D0I: https://doi.org/10.1016/B978-0-323-39055-2.00004-8

Quinn, P. J., Carter, M. E., Markey, B., and Carter, G. R. (2002). Clinical Veterinary Microbiology and microbial disease, Black well sciences. Publishing Wolf Spain, 2, 261-267.

Taylor, J. D., Fulton, R. W., Dabo, S. M., Lehenbauer, T. W., and Confer, A. W. (2010). Comparison of genotypic and phenotypic characterization methods for Pasteurella multocida isolates from fatal cases of bovine respiratory disease. Journal of veterinary diagnostic investigation, 22(3), 366-375. DOI: https://doi.org/10.1177\%2F10406387100-2200304

Townsend, K. M., Boyce, J. D., Chung, J. Y., Frost, A. J., and Adler, B. (2001). Genetic organization of Pasteurella multocida cap loci and development of a multiplex capsular PCR typing system. Journal of clinical microbiology, 39(3), 924-929. DOI: http://10.1128/JCM.39.3.924929.2001

Townsend, K. M., Frost, A. J., Lee, C. W., Papadimitriou, J. M., and Dawkins, H. J. (1998). Development of PCR assays for species-and type-specific identification of Pasteurella multocida isolates. Journal of clinical microbiology, 36(4), 1096-1100. DOI: https://doi.org/10.1128/JC-M.36.4.1096-1100.1998

Welsh, R. D., Dye, L. B., Payton, M. E., and Confer, A. W. (2004). Isolation and antimicrobial susceptibilities of bacterial pathogens from bovine pneumonia: 1994-2002. Journal of Veterinary Diagnostic Investigation, 16(5), 426-431. DOI:

https://doi.org/10.1177\%2F1-04063870401600510

Wilson, B. A., and Ho, M. (2013). Pasteurella multocida: from zoonosis to cellular microbiology. Clinical microbiology reviews, 26(3), 631-655. DOI: http://dx.doi.org/10.-1128/CMR.00024-13

\section{Tables}

Table 1. Oligonucleotide sequences used in P. multocida PCR assay. 


\begin{tabular}{|c|c|c|c|c|c|}
\hline $\begin{array}{l}\text { Sero- } \\
\text { groups }\end{array}$ & Gene & Primers & Sequence $\left(5^{\prime}\right.$ to $\left.3^{\prime}\right)$ & $\begin{array}{l}\text { Amplicon size } \\
\text { (bp) }\end{array}$ & Reference \\
\hline \multirow[t]{2}{*}{ All } & \multirow[t]{2}{*}{ KMT1 } & $\begin{array}{l}\text { KMT1T7- } \\
\text { F }\end{array}$ & ATCCGCTATTTACCCAGTGG & \multirow[t]{2}{*}{460} & \multirow[t]{2}{*}{$\begin{array}{l}\text { (Townsend et al., 1998; EL-Jakeen } \\
\text { et al. 2016) }\end{array}$} \\
\hline & & $\begin{array}{l}\text { KMT1SP6- } \\
\text { R }\end{array}$ & GCTGTAAACGAACTCGCCAC & & \\
\hline \multirow[t]{2}{*}{ A } & \multirow{2}{*}{$\begin{array}{l}\text { hyaD- } \\
\text { hyaC }\end{array}$} & capA-F & TGCCAAAATCGCAGTCAG & \multirow[t]{2}{*}{1044} & \multirow[t]{2}{*}{ (Townsend et al., 2001) } \\
\hline & & capA-R & TTGCCATCATTGTCAGTG & & \\
\hline \multirow[t]{2}{*}{ B } & \multirow[t]{2}{*}{$b c b D$} & capB-F & САTTTATCCAAGCTCCACC & \multirow[t]{2}{*}{760} & \multirow[t]{2}{*}{ (Townsend et al., 2001) } \\
\hline & & capB-R & GCCCGAGAGTTTCAATCC & & \\
\hline \multirow[t]{2}{*}{ D } & \multirow[t]{2}{*}{$d c b F$} & capD-F & TTACAAAAGAAAGACTAGGAGCCC & \multirow[t]{2}{*}{657} & \multirow[t]{2}{*}{ (Townsend et al., 2001) } \\
\hline & & capD-R & САТСТАСССАСТСААССАТАТСAG & & \\
\hline \multirow[t]{2}{*}{ E } & \multirow[t]{2}{*}{$e c b J$} & capE-F & TCCGCAGAAAATTATTGACTC & \multirow[t]{2}{*}{511} & \multirow[t]{2}{*}{ (Townsend et al., 2001) } \\
\hline & & capE-R & GCTTGCTGCTTGATTTTGTC & & \\
\hline
\end{tabular}

Table 2. Cultural and biochemical profile of $P$. multocida subspecies multocida isolates

\begin{tabular}{|ll|}
\hline Characteristics & P. multocida \\
\hline Growth on blood agar & Non- haemolytic growth \\
\hline Oxidase & No growth \\
\hline Catalase & Positive \\
\hline Ornithin decarboxylase (ODC) & Positive \\
\hline Indole production & Positive \\
\hline Nitrate reduction & Positive \\
\hline Urease & Negative \\
\hline Methyl Red (MR) & Negative \\
\hline Citrate & Negative \\
\hline Voges-prokauer (VP) & Negative \\
\hline Glucose & Positive \\
\hline Sucrose & Positive \\
\hline Dulcitol & Negative \\
\hline Mannitol & Positive \\
\hline Maltose & Negative \\
\hline Sorbitol & Positive \\
\hline D-xylose & Positive \\
\hline
\end{tabular}

Table 3. Isolation frequency of $P$. multocida from study areas 


\begin{tabular}{|c|c|c|c|c|c|c|c|c|c|}
\hline \multirow[t]{2}{*}{ Study animal } & \multicolumn{2}{|c|}{ Sample } & \multicolumn{5}{|c|}{ P. multocida isolates and study area } & \multirow[t]{2}{*}{ Total } & \multirow[t]{2}{*}{$x^{2}$ square (P-value) } \\
\hline & Type & Size & Asosa & Bale-Robe & Bishoftu & Mekele & Yabelo & & \\
\hline \multirow[t]{2}{*}{ Calves } & Swab & $25 / 125$ & $8.0 \%$ & $16.0 \%$ & $28.0 \%$ & $12.0 \%$ & $20.0 \%$ & $16.8 \%$ & \multirow{7}{*}{0.02} \\
\hline & Lung & $9 / 45$ & $22.2 \%$ & $33.3 \%$ & $44.4 \%$ & $22.2 \%$ & $33.3 \%$ & $31.11 \%$ & \\
\hline Total & & $34 / 170$ & $11.76 \%$ & $20.59 \%$ & $32.35 \%$ & $14.7 \%$ & $23.53 \%$ & $20.59 \%$ & \\
\hline \multirow[t]{2}{*}{ Adult cattle } & Swab & $15 / 75$ & - & $20.0 \%$ & $26.67 \%$ & - & $6.67 \%$ & $10.67 \%$ & \\
\hline & Lung & $31 / 155$ & $9.68 \%$ & $12.9 \%$ & $16.13 \%$ & $6.45 \%$ & $12.9 \%$ & $11.61 \%$ & \\
\hline Total & & $46 / 230$ & $6.52 \%$ & $15.22 \%$ & $19.56 \%$ & $4.35 \%$ & $10.87 \%$ & $11.30 \%$ & \\
\hline Total & & $80 / 400$ & $8.75 \%$ & $17.5 \%$ & $25.0 \%$ & $8.75 \%$ & $16.25 \%$ & $15.25 \%$ & \\
\hline
\end{tabular}

Table 4. Biovar characteristics of the current $P$. multocida isolates.

\begin{tabular}{|c|c|c|c|c|c|c|c|c|c|c|}
\hline \multicolumn{9}{|c|}{ Sugar Fermentation } & \multirow{2}{*}{$\begin{array}{l}\text { Biovar } \\
\text { type }\end{array}$} & \multirow{2}{*}{$\begin{array}{l}\text { Isolation } \\
\text { percentage }\end{array}$} \\
\hline Trehalose & Galactose & $\begin{array}{l}\text { D- } \\
\text { Xylose }\end{array}$ & Arabinose & Mannitol & Lactose & Sorbitol & Maltose & Glucose & & \\
\hline+ & + & + & - & + & + & + & - & + & 1 & $7(11.47 \%)$ \\
\hline+ & + & + & - & + & - & + & - & + & 2 & $4(6.56 \%)$ \\
\hline- & + & + & - & + & - & + & - & + & 3 & $\begin{array}{l}48 \\
(78.69 \%)\end{array}$ \\
\hline- & + & + & - & + & + & + & - & + & 12 & $\begin{array}{l}2 \\
(3.28 \%)\end{array}$ \\
\hline
\end{tabular}

Figures 


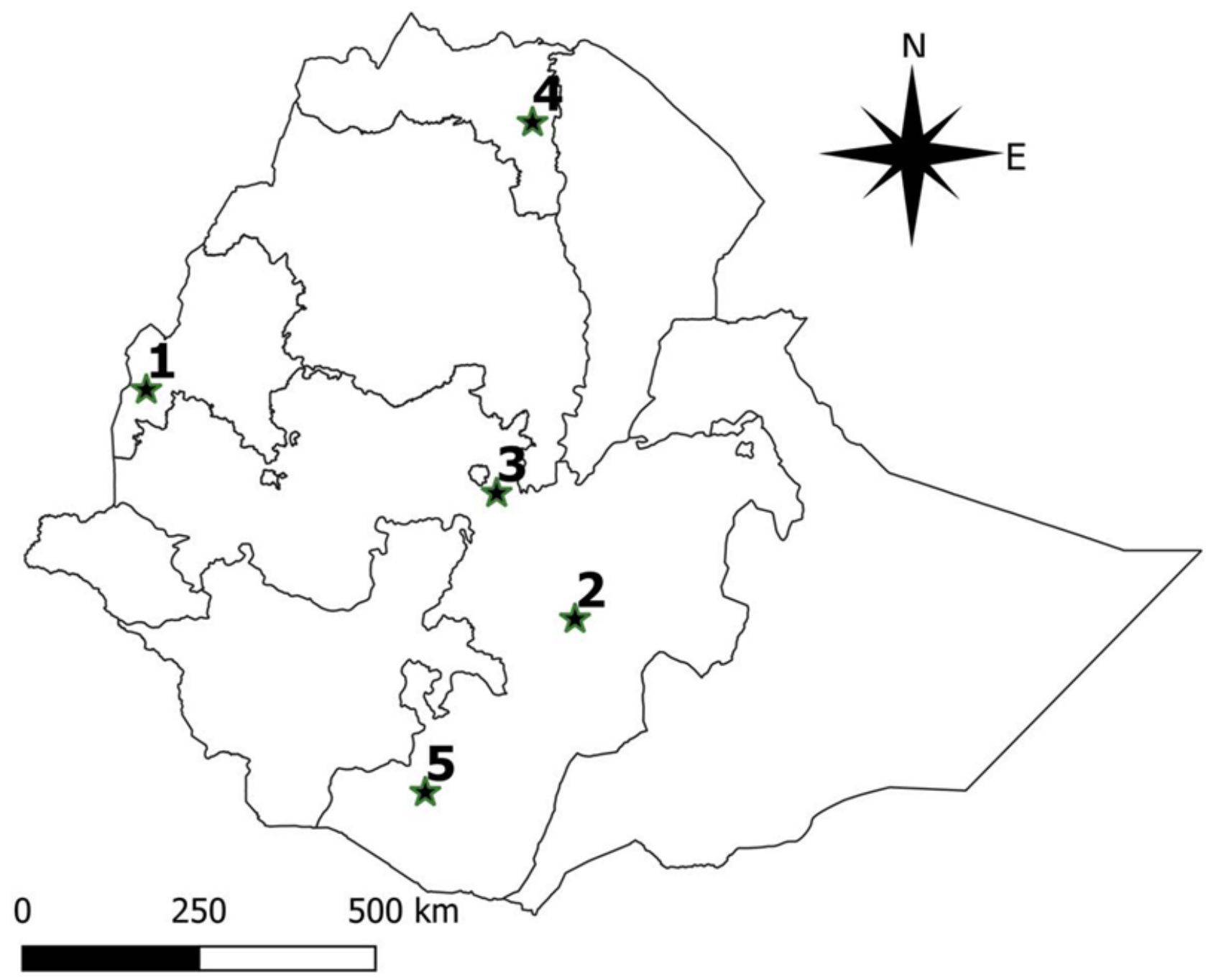

Figure 1

Map of Ethiopia indicating study areas where samples were collected; 1- Asosa; 2- Bale-Robe; 3- Bishoftu; 4- Mekele; and 5- Yabelo. The map was sketched using ArcGIS 9 software (ArcMapTM version 9.3, California, USA) 

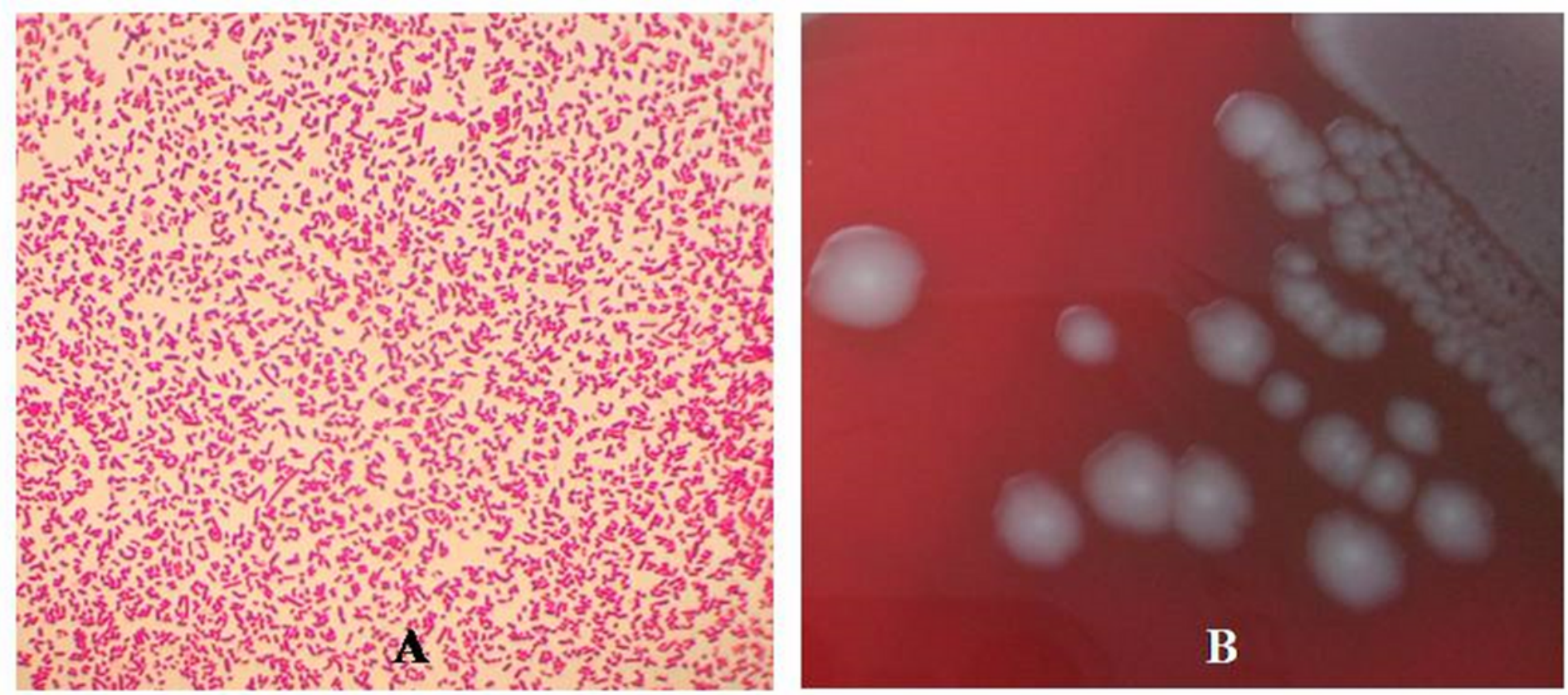

\section{Figure 2}

P. multocida isolate; (A) Gram staining smear and (B) non-hemolytic growth on blood agar.

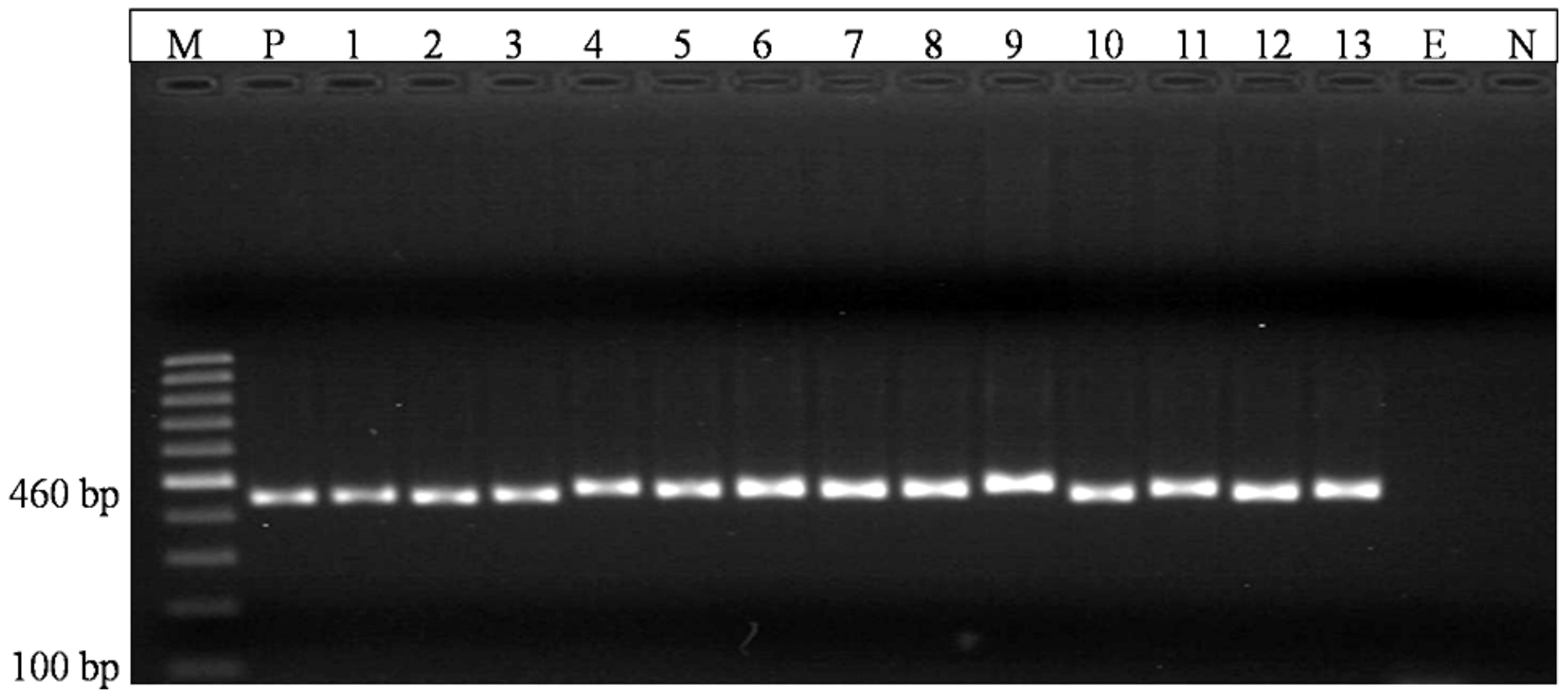

\section{Figure 3}

Agarose gel electrophoresis of PCR amplified product of KMT1 gene ( 460 bp) specific for P. multocida. Lane M: 100 bp DNA ladder; lane P: Positive control; lanes 1-13: tested samples; lane E: extraction control; lane N: negative control. 


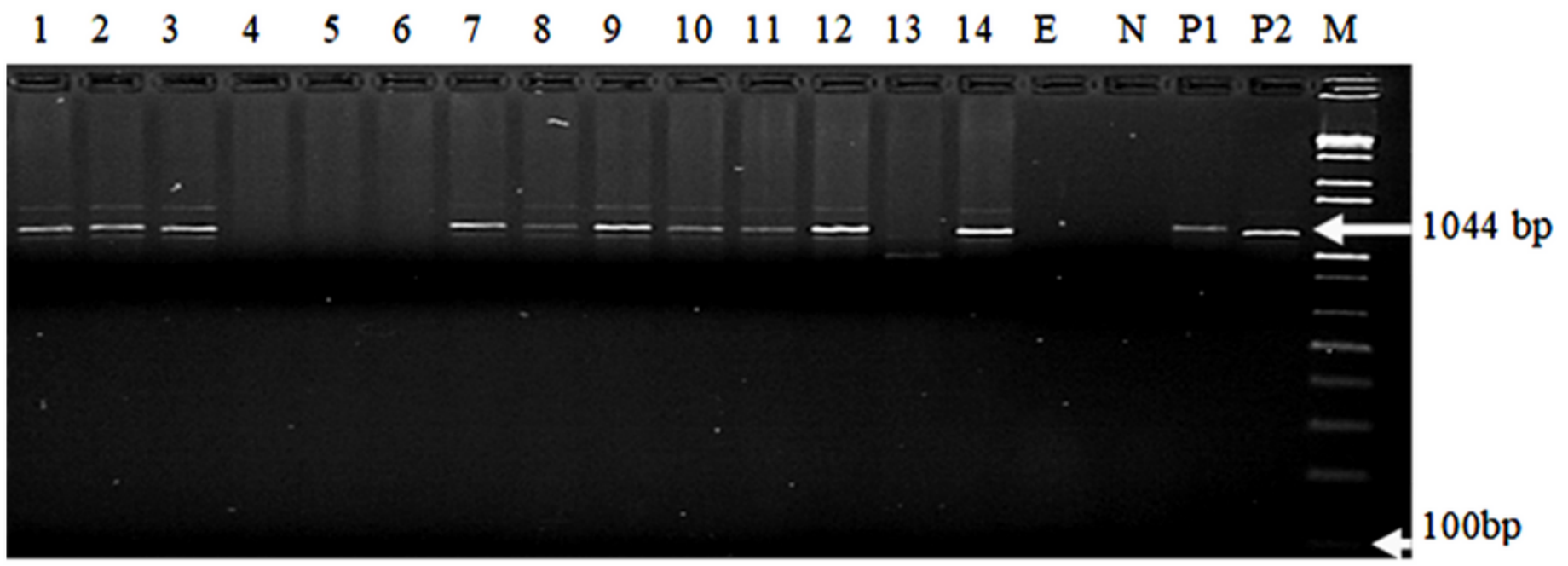

Figure 4

Agarose gel-electrophoresis of PCR amplified of serogroup A hyaD-hyaC gene ( 1044 bp). Lanes 1 to 3; lanes 7 to 14 are sample positive; lanes 4 to 6 and 13 are sample negative; lane E: extraction control; lane N: negative control; lane P1 and P2: Positive control; lane $\mathrm{M}: 1 \mathrm{~kb}$ plus DNA ladder. 